\title{
Amino Acid Profiles of Some Varieties of Rice, Soybean and Groundnut Grown in Ghana
}

\author{
Eshun Naomi Amankwah¹, Emmanuel Adu²,3*, Barimah John², Dossou VM² and Van Twisk $\mathbf{C}^{4}$ \\ ${ }^{1}$ Assistant Standards Officer, Ghana Standards Authority, Legon-Accra, Ghana \\ ${ }^{2}$ Lecturer, Department of Biochemistry, Kwame Nkrumah University of Science and Technology, Kumasi, Ghana \\ ${ }^{3}$ Biomass Refinery and Process Dynamics, WUR, Agrotechnology and Food Science, Wageningen, The Netherlands \\ ${ }^{4}$ Assistant, Research and Education, Food Quality and Design, Wageningen University and Research Centre, EV, Wageningen, The Netherlands
}

\begin{abstract}
Amino acid profiles of some Ghanaian varieties of rice, soybean and groundnut were investigated to augment existing data on their physicochemical properties and provide information to guide their application in weaning foods formulation. Five varieties of rice and four varieties each of groundnuts and soybeans were analyzed. Amino acids were separated using HPLC. Without postcolumn derivatization, Evaporative Light Scattering Detector (ELSD) was used to determine their concentrations against standard amino acids. Local rice varieties lacked tryptophan, valine, glycine, glutamic acid and lysine and histidine was present in only Nerica-2 variety but Nerica-1 variety had the highest total essential amino acid content of $36.42 \mathrm{~g} / \mathrm{kg}$. Quarshie soybean variety expressed all the amino acids under study and also had the highest total essential amino acids content of $169.14 \mathrm{~g} / \mathrm{kg}$. Sinkarzie and F-Mix groundnut varieties expressed all amino acids except tryptophan, with Sinkarzie having the highest total essential amino acids content of $100.62 \mathrm{~g} / \mathrm{kg}$.
\end{abstract}

Keywords: Amino acids profiles; Evaporative light Scattering Detector (ELSD); Grain legumes; HPLC

\section{Introduction}

The weaning of infants on gruels made from traditional cereal or root tuber staples like rice, maize or yam has made protein-energy malnutrition prevalent in infants in most developing countries $[1,2]$. Gruel made from cereals like maize, millet, sorghum or guinea corn is the major traditional weaning food in most developing countries, known as koko in Ghana and Ogi in Nigeria [3]. These gruels, although low in proteins and deficient in some essential amino acids still persist because the commercial weaning foods available for infant feeding are too expensive for low income families.

In an attempt to combat the persistent protein-energy malnutrition challenge, especially among children, in Africa, several strategies have been developed to produce healthy nutritious food, rich in proteins, for infant feeding; Rice, soybean and groundnut composites yielded diets with improved nutritional composition [3]. Malted cereals, soybeans and groundnuts composites yielded diets rich in proteins and minerals [4]. Germinated sorghum, soybean, sesame and groundnut composited diet had high protein contents. Cowpeas, common beans and green peas served as good protein supplements for sorghum and finger millet based diets [5]. Rice, soybeans and groundnuts are cheap and readily available in Ghana and have been recommended as composites for infant weaning diets.

Cereal-legume combinations could therefore yield low-cost diets with improved nutritional contents for infant weaning in Africa. However information for the right proportions of cereals and legumes for infant weaning food formulation is limited. This is because the exact nutritional profiles of traditional cereals and legumes are not known. Thus, weaning foods formulated from cereals and legume composites could still be deficient in some essential micro or macro nutrients. The study seeks to determine the amino acid profiles of the predominant varieties of rice, soybean and groundnuts grown in Ghana. This is necessary to provide information to facilitate the formulation of lowcost weaning foods with the optimum protein and amino acid profile, for infant growth and metabolism.

\section{Materials and Methods}

The rice, soybean and groundnut varieties were obtained from the Crops Research Institute, Fumesua, Kumasi and the Savannah Agriculture Research Institute, Tamale.

Rice varieties: Sikamo, Digang, Jasmine-85, Nerica-1 and Nerica-2

Soybean varieties: Salintuya, Quarshie, Anidaso and Jenguma

Groundnut varieties: Sinkarzie, F-mix, Chinese and Manipinta

\section{Sample preparation}

Moisture content of all samples were between 4-5\%. About 40 mg previously milled sample (using the Retchmill machine) was mixed with $5 \mathrm{ml}$ of $3 \%$ Phenol in $6 \mathrm{~N}$ Hydrochloric acid in glass tubes. Samples were incubated at $110^{\circ} \mathrm{C}$ for 16 hours in a heating block (Liebisch), cooled and $1 \mathrm{ml}$ of standard solution $(0.656 \mathrm{mg} / \mathrm{ml}$ norleucine) was pipetted into the glass tube and mixed. The mixture was filtered using Whatman 5951/2 filter paper and washed repeatedly with water. The resulting supernatant was divided into $1 \mathrm{ml}$ portions and dried in a Rotavap centrifuge (Thermo Electron, Asheville, NC, USA) under vacuum at $60^{\circ} \mathrm{C}$ for $2-3$ hours to remove the excess water and $\mathrm{HCl}$. After complete drying the hydrolysate was suspended in 1 $\mathrm{ml}$ buffer A (5 mM Heptafluorobutyric acid/0.7\% Trifluoroacetic acid) and untrasonicated for 15 minutes. Subsequently the samples were filtered through $0.45 \mathrm{um}$ filter for HPLC analysis. Measurements were conducted in duplicates for each variety.

*Corresonding author: Emmanuel Adu, Lecturer, Department of Biochemistry, Kwame Nkrumah University of Science and Technology, Kumasi, Ghana, E-mail: eamankay@gmail.com

Received November 27, 2014; Accepted January 22, 2014; Published January 29, 2015

Citation: Amankwah EN, Adu E, John B, Dossou VM, Van Twisk C (2015) Amino Acid Profiles of Some Varieties of Rice, Soybean and Groundnut Grown in Ghana. J Food Process Technol 6: 420. doi:10.4172/2157-7110.1000420

Copyright: ( 2015 Amankwah EN, et al. This is an open-access article distributed under the terms of the Creative Commons Attribution License, which permits unrestricted use, distribution, and reproduction in any medium, provided the original author and source are credited. 


\section{HPLC Analysis of Amino Acids in Samples}

In this research, sample concentration for HPLC was $6.67 \mathrm{mg} /$ $\mathrm{ml}$, injected volume, $20 \mu \mathrm{l}$ and flowrate, $1 \mathrm{ml} / \mathrm{min}$. Chromatographic analysis was performed using the HPLC (SP thermo separation products) and ELSD (Polymer laboratories, PL-ELS2100, USA). The solvent system consisted of two buffers. Buffer A ( $0.653 \mathrm{ml} 5 \mathrm{mM} \mathrm{98 \%}$ heptafluorobutyric acid in $7 \mathrm{ml} 0.7 \%$ trifluoroacetic acid solution) and buffer B (acetonitrile). Samples were injected onto the HPLC column (Grace Alltech Prevail C18 $5 \mu \mathrm{m}$ column, $4.6 \times 250 \mathrm{~mm}$ ). Stepwise elution was used beginning with $0 \% \mathrm{~B}$ or $100 \% \mathrm{~A}$ for 6 mins, followed by $15 \%$ B for 2 mins then $35 \%$ B for 17 min and finally held at $0 \%$ B for $5 \mathrm{~min}$. The nebulisation and the evaporation temperatures, and the nitrogen flow rate were optimised at $60^{\circ} \mathrm{C}$ and $2.0 \mathrm{l} / \mathrm{min}$, respectively.

Calibration curves were prepared for each amino acid standard. Area was plotted against concentration. Power trend lines were calculated from 5 dilutions. Regression coefficients were found in the range of 0.95-1.0. No correction factor was used for the internal standard because recovery was approximately $100 \%$.

\section{Statistical analysis}

The data obtained was analyzed using ANOVA. The significant differences between factors were determined using the Tukey's HSD test at $95 \%$ confidence level $(\mathrm{p}<0.05)$. The statistical tool used was STATGRAPHICS Centurion Version XIV.I.

\section{Results and Discussion}

A total of sixteen (16) amino acids, eight (8) essential and seven (7) nonessential, were detected using the HPLC-ELSD. Glutamic acid and Lysine however, eluted together for soybean and groundnuts and were recorded as such. The method could not detect glutamic acid and lysine in rice. This may be due to the hydrolyses procedure which causes variation in the determined and composition of aminoacids. Asparagine and glutamine were converted to their corresponding acids during the hydrolysis procedure. Cysteine and Methionine were oxidized into cystic acid and methionsulphon in the rice samples but could not be extracted from soybean and groundnut samples.

All rice varieties investigated were deficient in the essential amino acids (EEA) tryptophan, valine and lysine as well as the nonessential amino acids (NEEA) glycine and glutamic acid. All varieties, except Nerica-2, were deficient in histidine while Digang was deficient in proline. Threonine was the most predominant essential amino acid in the rice varieties, ranging from $10.70 \mathrm{~g} / \mathrm{kg}$ for Digang and $21.17 \mathrm{~g} / \mathrm{kg}$ in Nerica-1 while the predominant nonessential amino acid was Serine, ranging from $1.53 \mathrm{~g} / \mathrm{kg}$ for Jasmine- 85 to $29.30 \mathrm{~g} / \mathrm{kg}$ in Nerica-1. The total EEA for all five varieties ranged from $36.42 \mathrm{~g} / \mathrm{kg}$ to $20.52 \mathrm{~g} / \mathrm{kg}$ while total NEEA ranged from $26.16 \mathrm{~g} / \mathrm{kg}$ to $54.90 \mathrm{~g} / \mathrm{kg}$ with Nerica-1 having the highest and Digang the lowest in both cases. The amino acid profile of the different rice varieties is shown in Table 1.

The amino acid profile of Nerica-1 rice compared well to Thai rice having total essential amino acid content of $34.68 \mathrm{~g} / \mathrm{kg}$ [6]. The rice variety, environment and/or soil type for rice cultivation as well as preharvest and postharvest practices account for differences in nutritional composition.

All the local soybean varieties had good amino acid profiles. All the essential and nonessential amino acids were detected in Quarshie soybeans, while Salintuya and Anidaso soybeans were deficient in tryptophan and Jenguma soybean was deficient in histidine and proline. Threonine was the most abundant essential amino acid in the

\begin{tabular}{|l|c|c|c|c|c|}
\hline Amino Acid & Digang & Nerica-1 & Jasmine-85 & Nerica-2 & Sikamo \\
\hline Glutamic acid+Lysine & - & - & - & - & - \\
\hline Histidine & - & - & - & 0.92 & - \\
\hline Threonine & $10.70^{\mathrm{a}}$ & $21.17^{\mathrm{e}}$ & $11.86^{\mathrm{b}}$ & $17.58^{\mathrm{d}}$ & $13.49^{\mathrm{c}}$ \\
\hline Isoleucine & $1.96^{\mathrm{a}}$ & $3.55^{\mathrm{e}}$ & $2.04^{\mathrm{b}}$ & $3.51^{\mathrm{d}}$ & $2.98^{\mathrm{c}}$ \\
\hline Leucine & $4.13^{\mathrm{a}}$ & $6.81^{\mathrm{d}}$ & $4.82^{\mathrm{b}}$ & $7.27^{\mathrm{e}}$ & $5.95^{\mathrm{c}}$ \\
\hline Phenylalanine & $3.55^{\mathrm{a}}$ & $4.91^{\mathrm{d}}$ & $3.80^{\mathrm{b}}$ & $5.03^{\mathrm{e}}$ & $4.45^{\mathrm{c}}$ \\
\hline Tryptophan & - & - & - & - & - \\
\hline Valine & - & - & - & - & - \\
\hline Total EAA & 20.72 & $36.42^{2}$ & 22.5 & 33.36 & 26.88 \\
\hline Glycine & - & - & - & - & - \\
\hline Serine & $13.69^{\mathrm{b}}$ & $29.30^{\mathrm{e}}$ & $12.53^{\mathrm{a}}$ & $17.03^{\mathrm{d}}$ & $15.71^{\mathrm{c}}$ \\
\hline Aspartic acid & $4.72^{\mathrm{a}}$ & $7.56^{\mathrm{e}}$ & $5.07^{\mathrm{b}}$ & $7.50^{\mathrm{d}}$ & $5.86^{\mathrm{c}}$ \\
\hline Alanine & $3.46^{\mathrm{a}}$ & $7.27^{\mathrm{e}}$ & $4.22^{\mathrm{b}}$ & $7.14^{\mathrm{d}}$ & $5.32^{\mathrm{c}}$ \\
\hline Tyrosine & $1.07^{\mathrm{a}}$ & $2.93^{\mathrm{e}}$ & $1.50^{\mathrm{b}}$ & $2.70^{\mathrm{d}}$ & $2.10^{\mathrm{c}}$ \\
\hline Proline & - & $2.11^{\mathrm{c}}$ & $1.52^{\mathrm{a}}$ & $2.28^{\mathrm{d}}$ & $1.68^{\mathrm{b}}$ \\
\hline Arginine & $3.17^{\mathrm{a}}$ & $5.76^{\mathrm{e}}$ & $3.88^{\mathrm{b}}$ & $5.71^{\mathrm{d}}$ & $4.44^{\mathrm{c}}$ \\
\hline Total NEAA & 26.16 & 54.9 & 28.68 & 42.36 & 35.16 \\
\hline
\end{tabular}

*Different letters in the same row between corresponding pairs indicates significant differences $(P<0.05)$ by Tukey's test.

Not detected

Table 1: Amino Acid Composition of Ghanaian rice varieties (g/kg).

\begin{tabular}{|l|c|c|c|c|}
\hline Amino Acid & Quarshie & Salintuya & Anidaso & Jenguma \\
\hline Glutamic acid+Lysine & $23.70^{\mathrm{c}}$ & $20.16^{\mathrm{a}}$ & $24.24^{\mathrm{d}}$ & $20.28^{\mathrm{b}}$ \\
\hline Histidine & $7.32^{\mathrm{c}}$ & $7.02^{\mathrm{b}}$ & $6.78^{\mathrm{a}}$ & - \\
\hline Threonine & $57.48^{\mathrm{c}}$ & $58.80^{\mathrm{d}}$ & $54.36^{\mathrm{a}}$ & $54.72^{\mathrm{b}}$ \\
\hline Isoleucine & $20.16^{\mathrm{d}}$ & $20.04^{\mathrm{c}}$ & $19.38^{\mathrm{b}}$ & $19.14^{\mathrm{a}}$ \\
\hline Leucine & $32.40^{\mathrm{d}}$ & $31.44^{\mathrm{b}}$ & $31.56^{\mathrm{c}}$ & $30.60^{\mathrm{a}}$ \\
\hline Phenylalanine & $21.36^{\mathrm{d}}$ & $20.64^{\mathrm{b}}$ & $20.76^{\mathrm{c}}$ & $19.98^{\mathrm{a}}$ \\
\hline Tryptophan & $2.46^{\mathrm{a}}$ & - & - & $3.12^{\mathrm{b}}$ \\
\hline Valine & $4.26^{\mathrm{b}}$ & $6.78^{\mathrm{d}}$ & $3.90^{\mathrm{a}}$ & $6.48^{\mathrm{c}}$ \\
\hline Total EAA & 169.14 & 167.94 & 160.98 & 154.32 \\
\hline Glycine & $16.86^{\mathrm{d}}$ & $15.18^{\mathrm{a}}$ & $16.68^{\mathrm{c}}$ & $15.60^{\mathrm{b}}$ \\
\hline Serine & $46.08^{\mathrm{a}}$ & $48.30^{\mathrm{b}}$ & $55.92^{\mathrm{d}}$ & $52.44^{\mathrm{c}}$ \\
\hline Aspartic acid & $41.53^{\mathrm{d}}$ & $39.36^{\mathrm{b}}$ & $39.00^{\mathrm{a}}$ & $39.78^{\mathrm{c}}$ \\
\hline Alanine & $69.12^{\mathrm{c}}$ & $67.98^{\mathrm{b}}$ & $63.96^{\mathrm{a}}$ & $75.30^{\mathrm{d}}$ \\
\hline Tyrosine & $14.52^{\mathrm{d}}$ & $14.10^{\mathrm{c}}$ & $13.38^{\mathrm{b}}$ & $13.20^{\mathrm{a}}$ \\
\hline Proline & $21.18^{\mathrm{a}}$ & $21.48^{\mathrm{c}}$ & $21.24^{\mathrm{b}}$ & - \\
\hline Arginine & $16.80^{\mathrm{a}}$ & $23.58^{\mathrm{d}}$ & $23.16^{\mathrm{c}}$ & $21.78^{\mathrm{b}}$ \\
\hline Total NEAA & 226.09 & 229.98 & 233.34 & 218.1 \\
\hline
\end{tabular}

Different letters in the same row between corresponding pairs indicates significant differences $(P<0.05)$ by Tukey's test.

Not detected

Table 2: Amino Acid Composition of Ghanaian soybean varieties $(\mathrm{g} / \mathrm{kg})$.

soybean varieties, ranging from $54.36 \mathrm{~g} / \mathrm{kg}$ to $58.80 \mathrm{~g} / \mathrm{kg}$ while alanine was the predominant non essential amino acid ranging from $63.96 \mathrm{~g} / \mathrm{kg}$ to $75.30 \mathrm{~g} / \mathrm{kg}$. Total EEA ranged from $154.32 \mathrm{~g} / \mathrm{kg}$ to $169.14 \mathrm{~g} / \mathrm{kg}$ while total NEEA ranged from $218.10 \mathrm{~g} / \mathrm{kg}$ to $233.34 \mathrm{~g} / \mathrm{kg}$ with Quarshie having the highest and Jenguma the lowest in both cases as shown in Table 2 .

The local soybean varieties contained lower lysine, valine, histidine and tryptophan (from $2.46 \mathrm{~g} / \mathrm{kg}$ to $24.24 \mathrm{~g} / \mathrm{kg}$ ) when compared with Brazillian and USA soybeans which ranged from $4.51 \mathrm{~g} / \mathrm{kg}-100.58 \mathrm{~g} / \mathrm{kg}$. Threonine and alanine levels were about three times higher in the local varieties than soybeans from Brazil and USA while isoleucine, leucine and phenylalanine contents in the local soybeans were comparable to that of Brazil and USA [7].

Tryptophan was not detected in all four groundnut varieties. F-Mix and Sinkarzie expressed all the other amino acids investigated. Co- 
Citation: Amankwah EN, Adu E, John B, Dossou VM, Van Twisk C (2015) Amino Acid Profiles of Some Varieties of Rice, Soybean and Groundnut Grown in Ghana. J Food Process Technol 6: 420. doi:10.4172/2157-7110.1000420

\begin{tabular}{|l|c|c|c|c|}
\hline Amino Acid & Manipinta & Sinkarzie & F-Mix & Chinese \\
\hline Glutamic acid+Lysine & - & $10.32^{\mathrm{a}}$ & $10.20^{\mathrm{b}}$ & - \\
\hline Histidine & - & $4.08^{\mathrm{a}}$ & $3.64^{\mathrm{b}}$ & $2.10^{\mathrm{c}}$ \\
\hline Threonine & - & $41.64^{\mathrm{a}}$ & $34.74^{\mathrm{b}}$ & $38.58^{\mathrm{c}}$ \\
\hline Isoleucine & $12.78^{\mathrm{a}}$ & $10.14^{\mathrm{b}}$ & $10.32^{\mathrm{c}}$ & $8.10^{\mathrm{d}}$ \\
\hline Leucine & $24.12^{\mathrm{a}}$ & $18.12^{\mathrm{b}}$ & $17.82^{\mathrm{c}}$ & $14.28^{\mathrm{d}}$ \\
\hline Phenylalanine & $18.90^{\mathrm{a}}$ & $13.08^{\mathrm{b}}$ & $13.74^{\mathrm{c}}$ & $12.06^{\mathrm{d}}$ \\
\hline Tryptophan & - & - & - & - \\
\hline Valine & $11.28^{\mathrm{a}}$ & $3.24^{\mathrm{b}}$ & $3.72^{\mathrm{c}}$ & $6.30^{\mathrm{d}}$ \\
\hline Total EAA & 67.08 & 100.62 & 94.2 & 81.42 \\
\hline Glycine & $26.22^{\mathrm{a}}$ & $17.40^{\mathrm{b}}$ & $16.14^{\mathrm{c}}$ & - \\
\hline Serine & - & $31.73^{\mathrm{a}}$ & $30.48^{\mathrm{b}}$ & - \\
\hline Aspartic acid & $14.60^{\mathrm{a}}$ & $27.30^{\mathrm{b}}$ & $25.26^{\mathrm{c}}$ & $22.02^{\mathrm{d}}$ \\
\hline Alanine & - & $31.68^{\mathrm{a}}$ & $24.18^{\mathrm{b}}$ & $20.94^{\mathrm{c}}$ \\
\hline Tyrosine & $12.96^{\mathrm{a}}$ & $9.90^{\mathrm{b}}$ & $8.64^{\mathrm{c}}$ & $7.08^{\mathrm{d}}$ \\
\hline Proline & $11.16^{\mathrm{a}}$ & $7.30^{\mathrm{b}}$ & $7.32^{\mathrm{c}}$ & $6.78^{\mathrm{d}}$ \\
\hline Arginine & $5.46^{\mathrm{a}}$ & $22.63^{\mathrm{b}}$ & $22.62^{\mathrm{c}}$ & $16.92^{\mathrm{d}}$ \\
\hline Total NEAA & $70.6^{\mathrm{a}}$ & 147.94 & 133.4 & 73.74 \\
\hline
\end{tabular}

*Different letters in the same row between corresponding pairs indicate significan differences $(P<0.05)$ by Tukey's test.

- Not Detected

Table 3: Composition of amino acids in four Ghanaian groundnut varieties $(\mathrm{g} / \mathrm{kg})$.

eluting Glutamic acid and lysine as well as serine were not detected in Manipinta and Chinese. Histidine and threonine were also not detected in Manipinta while Chinese was lacking in glycine. Threonine $(34.74 \mathrm{~g} / \mathrm{kg}$ to $41.64 \mathrm{~g} / \mathrm{kg})$ and alanine $(20.94 \mathrm{~g} / \mathrm{kg}$ to $31.68 \mathrm{~g} / \mathrm{kg})$ were the predominant amino acids in Sinkarzie, F-Mix and Chinese while leucine $(2.12 \mathrm{~g} / \mathrm{kg})$ and glycine $(26.22 \mathrm{~g} / \mathrm{kg})$ were predominant in Manipinta as shown in Table 3. Sinkarzie groundnuts had the highest total EEA and total NEA of $100.62 \mathrm{~g} / \mathrm{kg}$ and $147.94 \mathrm{~g} / \mathrm{kg}$ respectively while Manipinta expressed the least total EEA and total NEA of 67.08 $\mathrm{g} / \mathrm{kg}$ and $70.60 \mathrm{~g} / \mathrm{kg}$ respectively.

All the groundnut varieties had lower total EEA than Indian JL groundnut variety $(121 \mathrm{~g} / \mathrm{kg})$ and USA peanuts $(127.43 \mathrm{~g} / \mathrm{kg})$ but threonine levels of the local groundnut varieties were about four times higher than in the Indian or USA groundnuts.

Tryptophan is essential in the manufacture of serotonin, needed for balancing mood and sleep patterns but was the least expressed amino acid in all the local rice, groundnut and soybean varieties [8]. Alanine was expressed in high amounts in almost all the rice, soybean and groundnut varieties. Alanine however can be produced by the body and is thus nonessential. Excess alanine in the diet may result in flushing and tingling in the muscles of humans and must therefore be regulated in weaning foods [9].

The FAO [10] recommends weaning foods to contain not less than $42 \mathrm{~g} / \mathrm{kg}$ each of lysine, leucine, isoleucine and valine, $28 \mathrm{~g} / \mathrm{kg}$ each of threonine, tyrosine and phenylalnine and $14 \mathrm{~g} / \mathrm{kg}$ tryptophan. With the exception of tryptophan requirements, weaning diets formulated with the local rice, soybean and groundnut varieties will not meet all other essential amino acid requirements. Thus, there is the need for fortification of the weaning diets with protein isolates.

\section{Conclusion}

While rice varieties were lacking in valine, glycine, glutamic acid

and lysine and histidine, soybean and groundnut varieties expressed most amino acids investigated. Nerica-1 rice, Quarshie soybean and Sinkarzie groundnut had the highest total EAA. The predominant amino acids in all varieties tested were threonine and serine. However, composites of rice, soybean and groundnut varieties in weaning foods will still present some deficiencies in the essential amino acid requirements of infants. Fortification of weaning diets, formulated with the local rice, soybeans and groundnut varieties investigated, with protein isolates is necessary to meet the protein energy requirement of infants.

\section{Acknowledgement} project.

The authors like to thank Lettink, F., for the technical assistance during this

\section{References}

1. Plahar WA, Hoyle NT (1991) Estimated protein quality of weaning blends from local cereals and legumes. Proceedings of the AAU/UNU international seminar, Accra, Ghana.

2. Lalude LO, Fashakin JB (2006) Development and Nutritional Assessment of a Weaning Food from Sorghum and Oil-Seeds, Pakistan Journal of Nutrition 5: $257-260$.

3. Eshun G, Kyei-Baffour N, Ackah P Y (2011) Nutrient content and sensory acceptability of a weaning diet formulated from mixtures of soya bean, groundnut and rice, African Journal of Food Science 5: 870-877.

4. Anigo KM, Ameh DA, Ibrahim S, Danbauchi SS (2010) Nutrient composition of complementary food gruels from malted cereals, soybeans and groundnut for use in North-Western Nigeria Afr J Food Sci 4: 65-72.

5. Muhimbulla HS, Issa-Zacharia A, Kinabo J (2011) Formulation and sensory evaluation of complementary foods from local, cheap and readily available cereals and legumes in Iringa, Tanzania Afr J Food Sci 5: 26-31.

6. Moongngarm A, Saetung N (2010) Comparison of chemical compositions and bioactive compounds of germinated rough rice and brown rice Food Chemistry 122: $782-788$.

7. Smith JA (1988) Economic Evaluation of Soybean and Sesame in Belize, A Report Submitted to the Belize Agribusiness Company and United States Agency for International Development.

8. Yogman MW, Zeisel SH, Roberts C (1982) Assessing Effects of Serotonin Precursors on Newborn Behavior J Psychiatr Res 17: 123-133.

9. Derave W, Ozdemir MS, Harris RC (2007) Beta-Alanine supplementation augments muscle carnosine content and attenuates fatigue during repeated isokinetic contraction bouts in trained sprinters. Journal on Applied Physiology 103: 1736-1743

10. FAO/WHO (1998) Preparation and use of Food-Based Dietary Guidelines, Report of a Joint FAO/WHO Consultation,WHO Technical Report series 880, Geneva. 